\title{
ASSESSMENT OF THE IMPACT OF CHANGES IN DEFORESTATION UNDER THE EFFECT OF SEVERE WINDSTORMS ON RUNOFF CONDITIONS IN SMALL RIVER BASINS
}

\author{
Zuzana ŠTEFUNKOVÁ ${ }^{1 *}$, Kamila HLAVČOVÁ ${ }^{1}$, Marija Mihaela LABAT $^{1}$
}

\begin{abstract}
Forests represent the most natural means of retaining water in a basin. Assessing the impact of a forest on a hydrological cycle is a very current topic that hydrologists and water managers deal with. The differences between site conditions and a forest itself, together with various methods of exploring this issue, lead to inconsistent opinions on the extent of the ability of a forest cover to prevent or minimize surface runoff.

This article is therefore focused on an assessment of the impact of changes in the composition of a forest under the effect of severe windstorms on runoff conditions in the selected river basin. The most severe windstorms in the last 25 years and their impact on changes in forest cover in the selected area of the Ipoltica River basin have been assessed in this article. The most significant severe windstorm in terms of its impact on changes in the forest communities was Filip, which occurred in the year 2007. Therefore, the impact of changes in forest cover on the given territory was examined for the period after the year 2007. The WetSpa rainfall-runoff model was used to assess the changes.
\end{abstract}

\section{Address}

1 Dept. of Land and Water Resources Management, Faculty of Civil Engineering, Slovak University of Technology in Bratislava, Bratislava, Slovakia

* Corresponding author: zuzana_stefunkova@stuba.sk

\section{Key words}

- Land use change,

- Severe windstorm,

- WetSpa model,

- Rainfall-runoff modeling.

\section{INTRODUCTION}

The occurrence of natural disasters and concerns about them are probably as old as humankind itself. In the territory of Slovakia, as well as in Europe, most natural disasters are caused by extreme weather conditions, especially floods that destroy technical facilities and property and threaten human life. As far as forests are concerned, the most widespread damage is caused by wind, but also by snow, ice, and local avalanches.

The number of calamities in forest communities is also increasing due to climate change conditions (Dorland et al., 1999; Fleischer et al., 2017). But as history, as well as the present, has shown, a natural forest cannot guarantee its full ability to withstand the effect of the wind or other natural elements (Siu-Ngan Lam, 2008; Kucna and Zúbrik, 2006).
Forests are not only a source of wood and other products but are also a chief component of a territory; they affect the circulation of both surface and underground water in the country. Forests affect not only the quantity of water, but also their quality and purity. Unlike other plant communities, forests are more extensive and long-lasting. Therefore, it can be said that forests are more effective in the water cycle in a country than other plants. The characteristics of a forest, including woody crops, can cause some changes in the circulation of water compared to unprotected soil or soil covered by other plant communities. Scientists since the early 20th century have explored the relationship between forests and drainage (Mind'áš and Škvarenina, 2010). After generalizing those findings, measurements and research results, it has been confirmed that forests have a retention capacity that is reflected by the retention of rainwater in the effluent; an accumulation capacity, which is reflected in the accumulation of 
water from precipitation on a large surface of a forest, on the soil, and also in the soil itself; and a retardation ability, which is characterized by the retardation of runoff by converting surface runoff to underground runoff (Roberts, 2009). There are many researchers in water management and hydrology that have mainly focused on the effect of land use changes on runoff and erosion processes (see, e.g., Burt and Slattery, 2006; He et al., 2013; Li et al., 2013; Ray et al., 2010; Rončák and Hlavčová, 2014) as well as the dynamics of these changes over time (Butt et al., 2015; Valent et al., 2016).

Based on the synthesis of a number of studies it can be concluded that hydrological responses to deforestations are highly variable, and often difficult to interpret. Anyway, the obvious finding is that the deforestation increases and reforestation decreases the annual flow. At the same time, deforestation increases flood peaks and volumes (Andréssian 2004), while forested catchments have greater infiltration rates, which may decrease catchment runoff (Zhang et al. 2014).

In the last few years, we have noticed several severe windstorms in Slovakia; they are often associated with the proliferation of insects, which also negatively impacts forest ecosystems.

The most significant of the severe windstorms that have affected our forests in recent years include Ivan (1996), Paulína (1999), Tamara (2001), Sabína and Klaudia (2002), Alžbeta (Elizabeth) (2004), Trojkrál'ová (2006), Kyrill (2007), Filip (2007), Gizela (2010), and Žofia (2014).

Among the most significant of the severe windstorms that have struck the Low Tatras, we can include the severe windstorms of Alžbeta, Filip, and Žofia (Figure 1).

Experts agree that the most disastrous severe windstorm for this territory was Alžbeta in November 2004 (Kucana and Zúbrik, 2006). At that time there was a low-pressure area in Slovakia, which was associated with a significant cold front that passed through the territory and was accompanied by severe wind gusts. The disaster was most evident in areas of the High and Low Tatras, especially in Orava and Slovenské Rudohorie. As of 31st December 2005, 5.3 mil. m³ of damaged wood, out of which spruce stands formed $90 \%$, was recorded. The period between 2005 and 2010 was essential for the development of insect pests in that region (Trebulová, 2014).
The severe windstorm Filip in August 2007 was caused by a storm that swept through Slovakia. This southern wind damaged forests, especially in the region of Rimavská Sobota. The wind then passed through a ridge of the Low Tatras, damaged its northern part, and ended up in Podtatranská kotlina. The volume of damaged wood was 1 mil. $\mathrm{m}^{3}$. Six hundred forty thousand $\mathrm{m}^{3}$ of the damaged trees were coniferous trees, out of which $94 \%$ were spruce stands. Three hundred sixty thousand $\mathrm{m}^{3}$ of the damaged trees were deciduous trees, especially beech (Trebulová, 2014).

Žofia in May 2014 was the second largest severe windstorm recently. Intensive rainfall activity was recorded in Slovakia at that time, especially during the previous two weeks. Due to differences in air pressure, an exceptional situation arose, when the wind speed reached up to $100 \mathrm{~km} / \mathrm{h}$. Due to the saturation of the soil and the extreme wind, the tree stands in a large area were destroyed. The volume of damaged wood was 4.07 mil. $\mathrm{m}^{3}$ (Trebulová, 2014).

The effect of the above three deforestation calamities was investigated for the Ipoltica River basin.

\subsection{Ipoltica River basin}

The Ipoltica River basin is located in the Low Tatras; from a geomorphological point of view, it is part of the Král'ovohol'ské Low Tatra (Figure 2). It is also part of the Low Tatras National Park. The Ipoltica River is a left-hand tributary of the Čierny Váh river. Its source is in the southwestern part of the basin around the Zadna hol'a and Oravcová hills. The basin, with its final profile in the Čierny Váh, has a catchment area of $86.28 \mathrm{~km}^{2}$. Its altitude ranges from about 730 $\mathrm{m}$ above sea level up to $1700 \mathrm{~m}$ asl. We can characterize the basin as having a relatively dense river network. The nature of the territory is mountainous, and forests, especially coniferous trees, cover most of the area. Sandy-loam soil and silty soil are the predominant soil species (Landscape Atlas of the Slovak Republic, 2002).

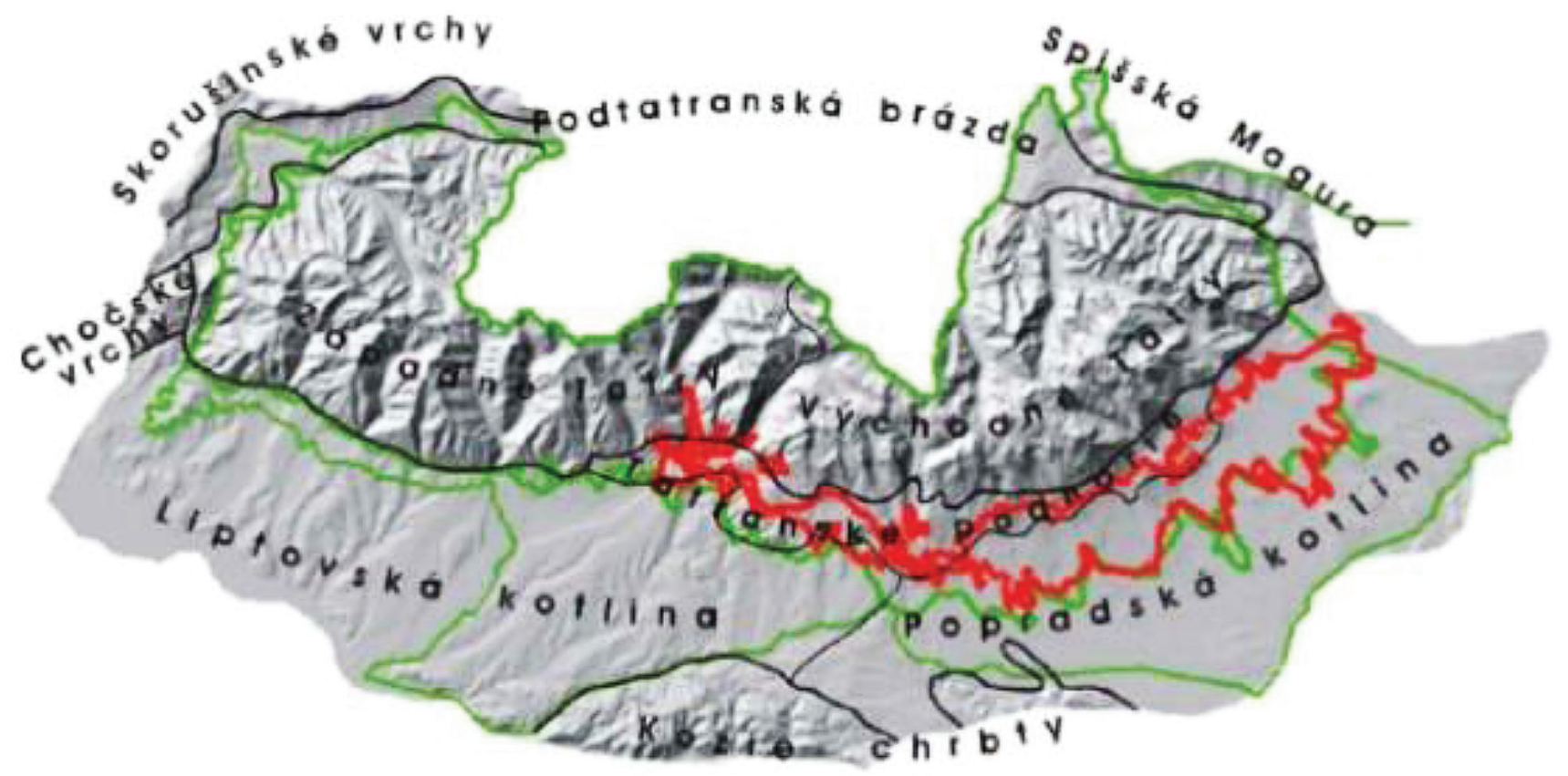

Fig. 1 Map of location of windstorms in Low Tatras (Kunca et al., 2014) 


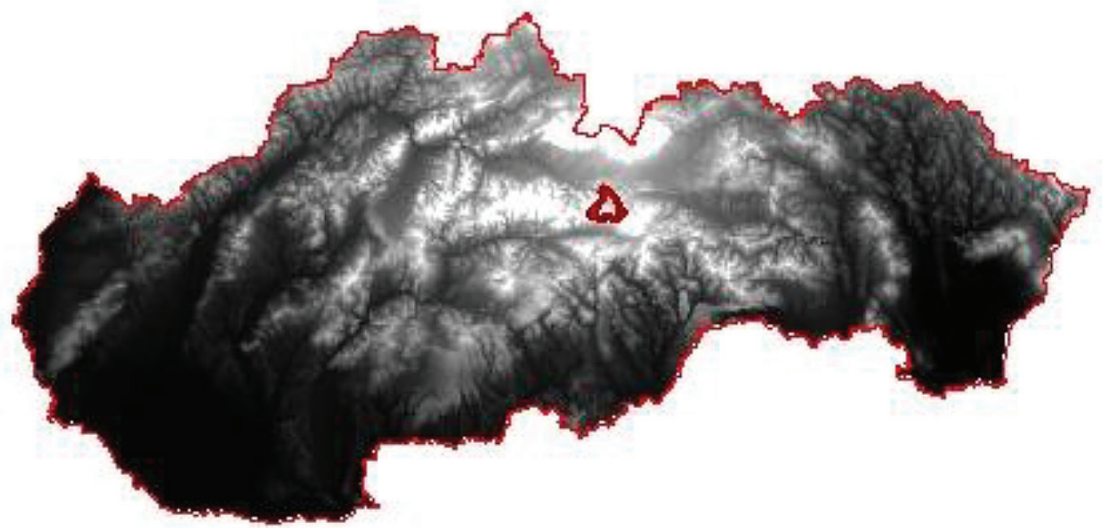

\section{Legend}
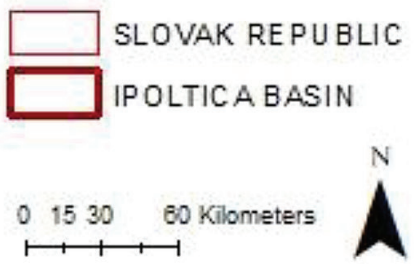

Fig. 2 Ipoltica River basin and its location within the Slovakia

\section{MATERIALS}

The effect of the three deforestation calamities was investigated based on Corine Land Cover (CLC) digital maps (Copernicus land monitoring service). CLC was originally initiated in 1985 to monitor the land cover of the European countries involved. Since then, five CLC monitorings have already been completed, which represent the following periods: 1990, 2000, 2006, 2012 and 2018. CLC distinguishes between 44 land cover classes with a resolution of $100 \mathrm{~m}$.

For this study, we have used the CLC maps for the years 1990, 2006, 2012, and 2018, as they describe land use before and after the significant calamities of Alžbeta, Filip, and Žofia. The analysis was comprised of a comparison of the individual land use types in the total area of the catchment. A comparison of the CLC maps is in Figure 3.
Tab. 1 Land use areas for various years for the Ipoltica River basin in $\mathrm{km}^{2}$

\begin{tabular}{l|cccc} 
Land use & 1990 & 2006 & 2012 & 2018 \\
\hline coniferous forest & 65.48 & 65.44 & 57.53 & 55.31 \\
pastures & 2.95 & 0.953 & 1.01 & 1.01 \\
agricultural land & 0.46 & 0.75 & 0.42 & 0.42 \\
transitional woodland-shrub & 11.17 & 11.61 & 19.64 & 21.87 \\
natural grassland & 3.29 & 2.64 & 2.49 & 2.49 \\
mixed forests & 2.89 & 4.87 & 5.16 & 5.16
\end{tabular}

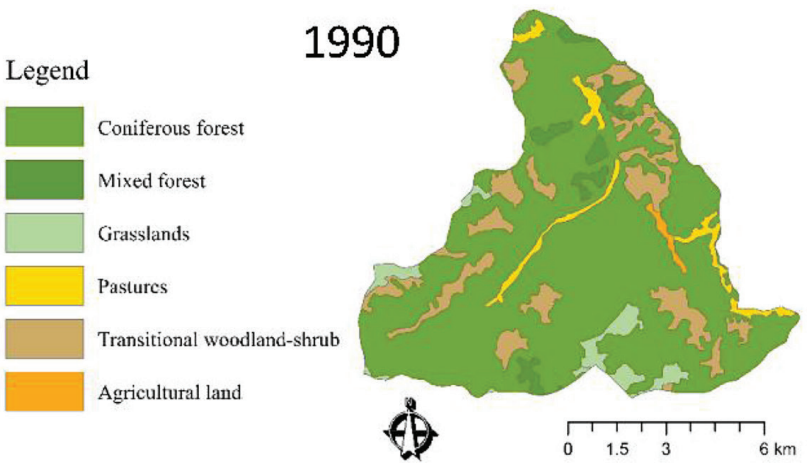

2012
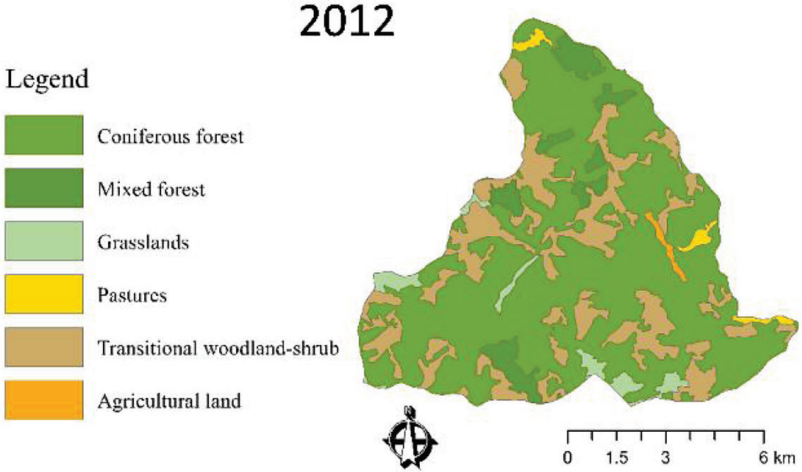

2006
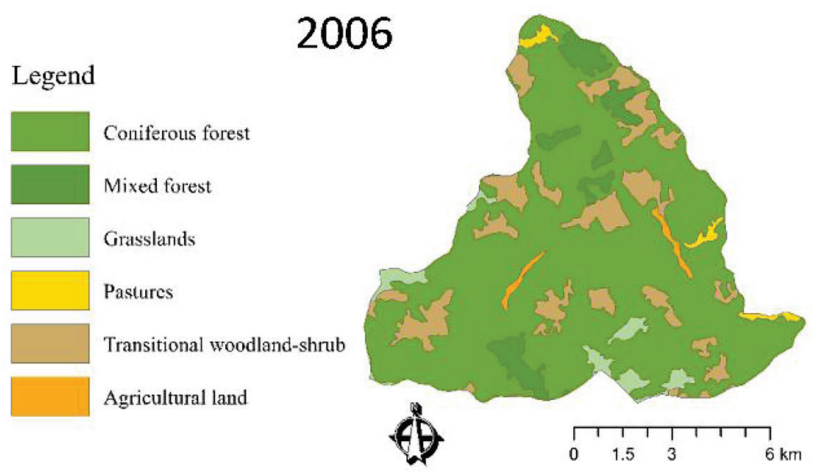

Fig. 3 Corine Land Cover maps for the Ipoltica River basin for the years 1990, 2006, 2012 and 2018

2018
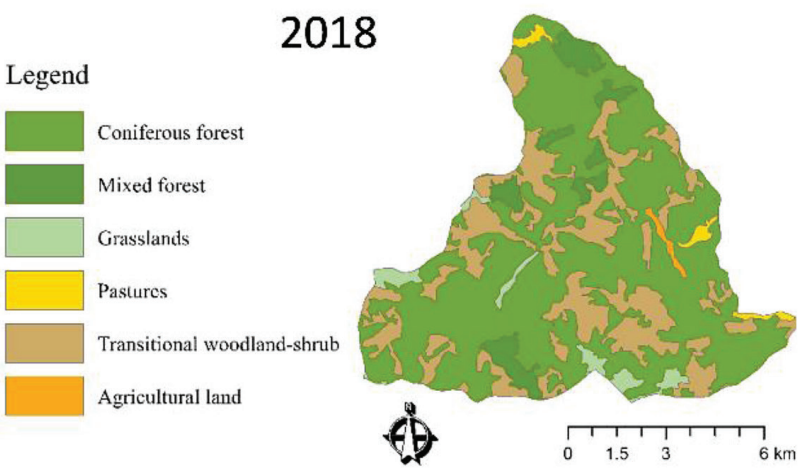
Based on a visual assessment of the maps from the years 1990 and 2018 , it can be seen that the land use has considerably changed. The coniferous forests have been most significantly reduced, and the area of transitional forests has increased. For a more accurate evaluation, the land use areas for various years are shown in Table 1 (Tab. 1).

From a comparison of the land use areas, it can be said that there was no major change in the forest composition between the years 1990 and 2006. The area of the coniferous forests declined by about 4 hectares; the grasslands, i.e., high and low grass, decreased by approximately 260 hectares. These changes increased the area of mixed forests and transitional forests. However, a significant change in the forest stands occurred when the periods before and after the year 2007 (CLC maps from the years 2006 and 2012) are compared, i.e., there was deforestation caused by Filip. The area of coniferous forests decreased by almost 800 ha, which represents $12.2 \%$ of the area of the coniferous forests. This area has been transformed into transitional forestry, which can be characterized as bare logs. Further development is documented by the land use map from 2018, where there were no significant changes in forest stands compared to 2012. As a result of the Žofia disaster in May 2014, the coniferous trees decreased by approximately 220 ha compared to 2012 .

Based on these results, we consider the most significant calamity for the Ipoltica River basin to be the Filip in 2007. A case study of the impact of the land use changes was therefore performed as a comparison of the land use changes for the years 1900-2006 and 2008-2018. The period before 2007 is considered as the reference period, and the period after 2007 as a period of significant changes in land use.

\section{METHODOLOGY}

To determine the effect of deforestation on drainage processes from a river basin, we chose the following methodology:

a) the calibration and validation of the parameters of the WetSpa rainfall-runoff model for the Ipoltica River basin using the measured input climate and hydrological data from the period that represents the stage before the severe windstorm in the year 2007 (1990-2006)

b) the simulation of the hydrological characteristics using a rainfall-runoff model driven by climate data from the period after the severe windstorm that occurred in the year 2007 (20082018)

c) the modification of the simulated data for the individual months of the period after the severe windstorm (2008-2018) by an error that occurred during the model's calibration (approx. 10\%)

d) an evaluation of the changes in the seasonal runoff redistribution after the severe windstorm by comparing the long-term mean monthly discharges in the river basin outlet.

\subsection{Calibration of the model}

The impact of the land use changes was assessed using the WetSpa fully distributed rainfall-runoff model since it is a model that takes into account the effects of land use on runoff-generating processes (Rončák et al., 2018). WetSpa is a physically-based and distributed hydrological model for predicting the water and energy transfer be- tween soil, plants and the atmosphere on regional or basin scales and daily time steps; it was developed at the Vrije Universiteit Brussels, Belgium (see, e.g., Wang et al., 1996; Batelaan et al., 1996; Liu and De Smed, 2004). The model conceptualizes a hydrological basin system composed of the atmosphere, the canopy, and the root, transmission, and saturation zones. A basin is divided into a number of grid cells in order to deal with any heterogeneity. Each cell is further divided into the bare soil and vegetated parts, for which the water and energy balance are maintained. Apart from direct measurements of the hydrometeorological and climatic variables, the model also exploits spatially distributed data such as the digital elevation model, maps of soil types, and maps of land use types. These are used to estimate various spatially distributed parameters such as the depth of the root zone, Manning's roughness coefficient, the soil porosity, the wilting point, flow accumulation, etc. (for a complete list of the spatially distributed parameters estimated, see Liu and De Smed (2004)). The model also contains 12 global parameters, which are constant for a whole catchment.

The 12 global parameters of the model were calibrated on a dataset from 1.1.1990 to 31.12.2007. During the calibration process, the spatially distributed parameters were estimated from the land use map from the year 2006 (before the calamity). The value of the Nash-Sutcliffe efficiency criterion that assessed the quality of the simulation was 0.64 , which represents an above average fit between the observed and simulated flows.

Figure 4 shows the results of the calibration as the long-term mean monthly values of the runoff in comparison with the measured data. According to this graph, we could expect some disagreements in the simulation results of the runoff. The most significant differences could be expected for the winter months of December and January and for the spring and summer months of March, June, July, and August. For these 6 months, there was an error in the calibrations that is just above 10\% (Tab. 2, Fig. 5). This inaccuracy could then be used for adjusting the simulated runoff values for the 2008-2018 period to obtain more accurate simulated values. The other months had a calibration error of 0 to $5 \%$, which is a very high degree of accuracy when calibrating a model.

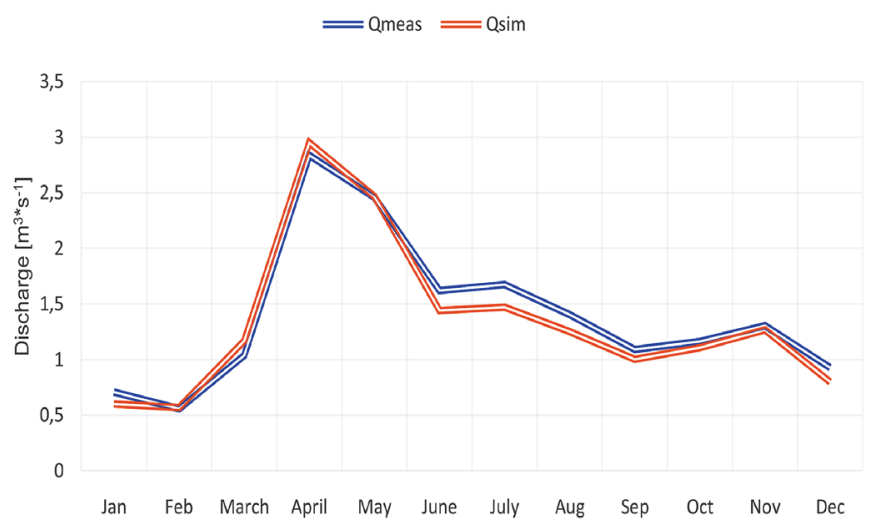

Fig. 4 Comparison of the simulated and measured long-term mean monthly discharges for the calibrated period (1990-2006) at the outlet of the Ipoltica River basin

Tab. 2 Percentage error of the calibration for each month of the year

\begin{tabular}{c|cccccccccccc}
\multicolumn{1}{c}{} & Jan & Feb & March & Apr & May & June & July & Aug & Sep & Oct & Nov & Dec \\
\hline Decrease or increase (-/+) & - & + & + & + & + & - & - & - & - & - & - & - \\
Change in Qsim and Qmeas [\%] & 15.1 & 2.1 & 12.8 & 4.0 & 0.3 & 11.1 & 12.2 & 10.9 & 8.1 & 5.0 & 2.8 & 13.9
\end{tabular}




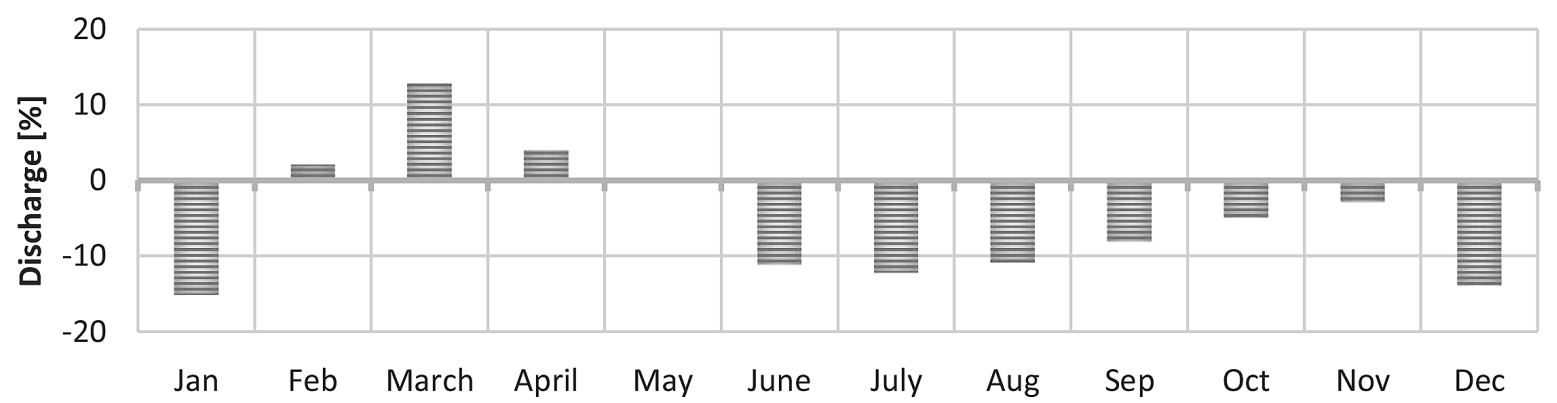

Fig. 5 Percentage error of the calibration for each month of the year

\subsection{Simulation of the runoff and evaluation of the impact of the land use changes on the catchment runoff}

Assuming that there would have been no severe windstorm in 2007, the runoff from the catchment that would have occurred in the next period (2008-2018) was simulated. The simulation was based on the same land utilization scenarios using the dataset of the hydrometeorological and climatic inputs from the period of 2008-2018. The global parameters used in this simulation were the parameters that were calibrated for the period 1990-2006. In the first stage, the WetSpa rainfall-runoff model was used to simulate the impact of the land use changes as a comparison of the measured runoff data for 2008-2018 (the actual data after the calamity, which greatly affected the composition of the forest in the area of interest) and the simulated data (the data that assumed that the windstorm had not occurred and that the land use had not changed). In this way, we could only compare the effect of the forest on the runoff, when other factors that could affect the outcome were filtered out. The results of the simulation are shown in Figure 6 as a comparison of the long-term mean monthly measured and simulated data.

The simulations show that the most significant changes in runoff could be expected for the winter months as well as for the summer months. The differences between the measured and simulated long-term mean monthly values of runoff for the years 2008-2018

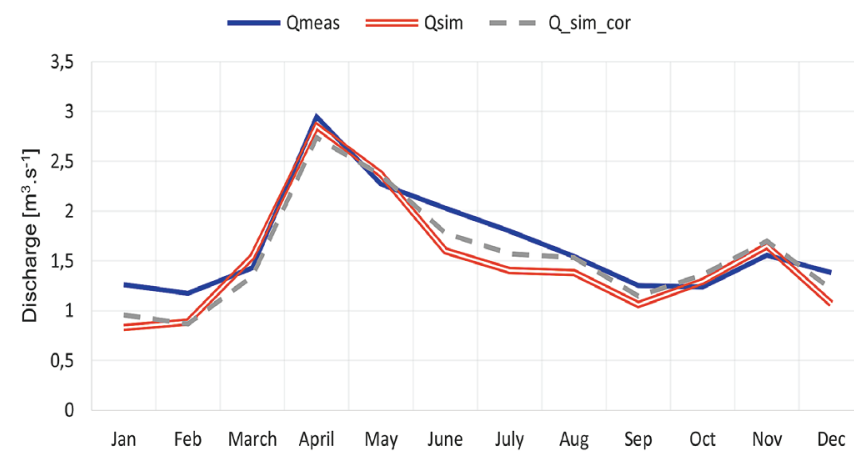

Fig. 6 Comparison of the measured, simulated, and corrected long-term mean monthly discharges for the period after the Filip windstorm (2008-2018) at the outlet of the Ipoltica River basin vary from $20-35 \%$ for the winter months and $10-20 \%$ for the summer months. These simulated runoff values were subsequently adjusted for the calibration error and were compared to the measured values that reflect the runoff from the territory after the Filip calamity in 2007. When comparing the measured values (Fig. 6 - blue color) and the modified simulated long-term mean monthly values of the runoff (Fig. 6 - gray color), it can be stated that Filip, which resulted in a loss of almost 1040 ha of coniferous forest, caused an increase in drainage of almost $25 \%$ in some months (Fig. 6, Tab. 3), despite the fact that in the years following the windstorm, the temperatures increased by as much as $2^{\circ} \mathrm{C}$, and the total rainfall decreased (by 15 to $60 \mathrm{~mm}$ for each month) compared to the period before Filip (Fig. 7).

\section{DISCUSSION AND CONCLUSION}

The main objective of this study was to assess the impact of the land use changes that took place in the Ipoltica River basin. In recent years (and especially after the severe windstorms in the Tatra Mountains in 2004 and 2007), assessing the impact of forests on runoff processes in the catchment area has been given increased attention. The forest is an exceptional community that, due to its indispensable natural functions, constitutes an essential condition for the existence and development of organisms, including humans.

For this research, the land use changes were evaluated based on Corine Land Cover maps (CLC). According to these maps, it can be concluded that the severe windstorm Filip in the year 2007 was the most disastrous windstorm of all the severe windstorms investigated since the year 1990 until now for the Ipoltica River basin. The volume of damaged wood was $1 \mathrm{mil} . \mathrm{m}^{3}$. Six hundred forty thousand $\mathrm{m}^{3}$ of the damaged trees were coniferous trees, out of which $94 \%$ were spruce stands. Three hundred sixty thousand $\mathrm{m}^{3}$ of the damaged trees were deciduous trees, especially beech (Tab. 1).

The results of the simulation confirm the fact that forests have a significant impact on the hydrological cycle. The forest accumulates and slowly releases large amounts of water. When a forest is destroyed, the runoff changes. Thanks to the forest cover, most of our streams and rivers have plenty of water even during periods of extreme drought. In the case of a very good structure and root system, forest soils can accumulate up to 200 liters of water per square meter per month, which slowly and evenly flows away (Bublinec, 2008). The forest therefore significantly reduces the risk of flooding, which

Tab 3 Comparison of the measured and corrected simulated long-term mean monthly discharges for the period after the Filip windstorm (2008-2018) at the outlet of the Ipoltica River basin

\begin{tabular}{l|ccccccccccccc}
\multicolumn{1}{l}{} & Jan & Feb & March & Apr & May & June & July & Aug & Sep & Oct & Nov & Dec \\
\hline Decrease or increase (-/+) & + & + & + & + & - & + & + & + & + & - & - & + \\
Change in Qsim and Qmeas [\%] & 24.2 & 26.1 & 6.0 & 7.1 & 4.0 & 12.4 & 12.6 & 0.7 & 8.5 & 9.7 & 9.1 & 11.8
\end{tabular}



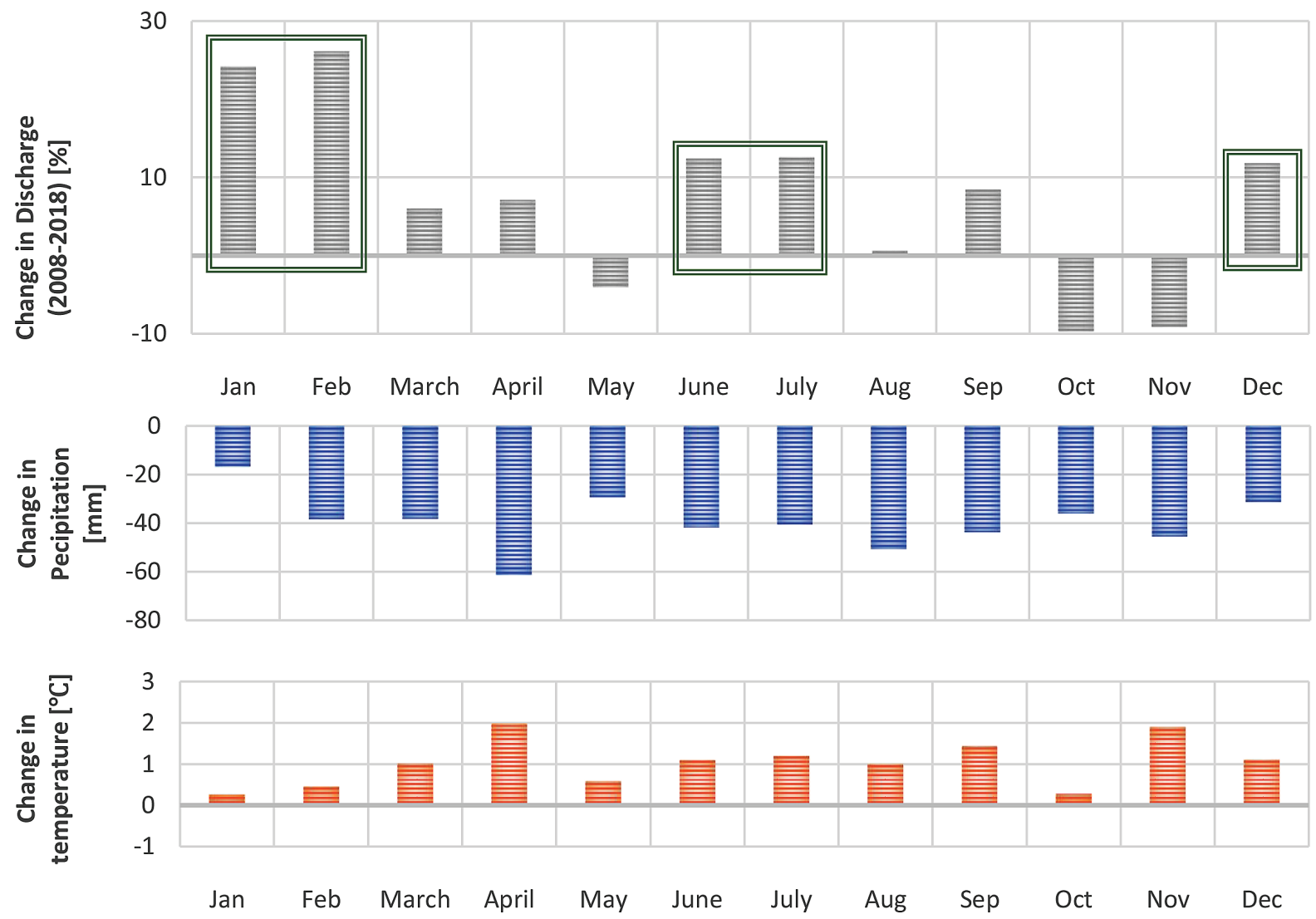

Fig. 7 Comparison of the measured and corrected simulated long-term mean monthly discharges for the period after the Filip windstorm (2008-2018) at the outlet of the Ipoltica River basin together with the evolution of the temperature and precipitation

is particularly significant in mountainous countries such as Slovakia. Out of the rainfall that reaches a forest, $20 \%$ will be captured in crowns as a so-called intercept loss, and $2 \%$ will run down the tree trunks to the soil surface. Physical vapor and the transpiration of herbaceous vegetation account for $19 \%$ of the rainfall and surface runoff for undisturbed soil account for less than $1 \%$. The amount of water transpired by a main crop is very high, so that the consumption of water by forest trees reaches $43 \%$. The remaining $17 \%$ drain into groundwater. When a forest is destroyed, the water during the rainy season is not accumulated and quickly drains from the basin. This also confirms our research where, despite the overall decrease in rainfall and increase in air temperature, the calamity caused an increase in runoff (up to 30\%) (Fig. 7) that could lead to subsequent negative consequences such as erosion, floods or the unbalanced redistribution of water in the country and the flows themselves. Therefore, estimating the impact of land use on runoff processes should be an essential part of integrated water resource management in river basins.

\section{Acknowledgement}

This work was supported by the Slovak Research and Development Agency under Contract No. APVV-18-0347 and APVV-150497. 


\section{REFERENCES}

Andréssian, V. (2004) Waters and forests: from historical controversy to scientific debate. Journal of Hydrology, 291, 1-27.

Batelaan, O. - Wang, Z. M. - De Smedt, F. (1996) An adaptive GIS toolbox for hydrological modelling, Application of geographic information systems in hydrology and water resources management. IAHS Publ. No. 235, pp. 3-9.

Bublinec, E. (2008) Forest - it's not just trees. Edition E - ecology of forest, professional ecological publications no.1. SAS Zvolen. ISBN 978-80-969525-5-7.

Burt, T. P. - Slattery, M. (2006) Land Use and Land Cover Effects on Runoff Processes: Agricultural Effects, Encyclopedia of Hydrological Sciences. Wiley, Chichester, pp. 1804-1812.

Butt, A. - Shabbir, R. - Ahmad, S. S. - Aziz, N. (2015) Land use change mapping and analysis using Remote Sensing and GIS: A case study of Simly watershed, Islamabad, Pakistan, The Egyptian Journal of Remote Sensing and Space Science, 18(2), pp. 251-259.

Copernicus land monitoring service, CORINE land cover, Available on: https://land.copernicus.eu/pan-european/corine-land-cover

Dorland, C. - Tol, R. S. - Palutikof, J. P. (1999) Vulnerability of The Netherlands and Northwest Europe to storm damage under climate change, Climatic change, 43(3), pp. 513-535.

Fleischer, P. - Pichler, V. - Fleischer Jr, P. - Holko, L. - Máliš, F. - Gömöryová, E. - Cudlín, P. - Holeksa, J. - Michalová Z. - Škvarenina, J. - Strělcová, K. - Střelcová, K. (2017) Forest ecosystem services affected by natural disturbances, climate and land-use changes in the Tatra Mountains, Climate Research, 73(1-2), pp. 57-71.

He, Y. - Lin, K. - Chen, X. (2013) Effect of Land Use and Climate Change on Runoff in the Dongjiang Basin of South China, Mathematical Problems in Engineering, 2013, 14. pp.

Kunca, A. - Zúbrik, M. (2006) Windstorm on 19 November 2004 (in Slovak), Národné lesnícke centrum, 2006 ISBN 80-8093-006-6.

Kunca, A. - Galko, J. - Zúbrik, M. (2014) What major calamities have affected our forests in recent years? Forest 2014/07, Lesmedium.

Landscape Atlas of the Slovak Republic (2002) 1st ed., Bratislava: Ministry of the Environment of the Slovak Republic, Banská Bystrica: Slovak Environmental Agency, pp. 344.
Li, L. - Wang, Y. - Liu, C. (2013) Effects of a land use changes on soil erosion in a fast developing area, International Journal of Environmental Science and Technology, 11(6), pp. 1549-1562.

Liu, Y. B. - De Smedt, F. (2004) WetSpa Extension, A GIS-based Hydrologic Model for Flood Prediction and Watershed Management (Documentation and User manual), Vrije Universiteit Brussel, Brussels, Belgium, pp. 126.

Mind'áš J. - Škvarenina J. (2010) Forests of Slovakia and water (in Slovak), Technical University in Zvolen, Zvolen.

Ray, D. K. - Pielke Sr., R. A. - Nair, U. S. - Niyogi, D. (2010) Roles of atmospheric and land surface data in dynamic regional downscaling, Journal of Geophysical Research, 115, D05102.

Roberts, J. M. (2009) The role of forests in the hydrological cycle, Forests and forest plants, 3, pp. 42-76.

Rončák, P. - Hlavčová, K. (2014) Impact of changes in forest associations from the generation of runoff in the Myjava River basin, Catchment processes in regional hydrology: Confronting experiments and modeling in Carpathian drainage basins, Bratislava, Slovakia and Sopron, Hungary, 27. Oct. 2014.

Rončák, P. - Maliariková, M. - Nosko, R. - Kordzakhia, G. Kordzakhia, M. (2018) Utilization of a Rainfall-Runoff Hydrological Model in Studies on the Impact of Land Use Changes: Case Study from Georgia, Bull. Georg. Natl. Acad. Sci, 12(2).

Siu-Ngan Lam, N. (2008) Methodologies for Mapping Land Cover/ Land Use and Its Change, Advances in Land Remote Sensing. Springer, The Netherlands, pp. 341-367.

Trebulová, J. (2014) 2004 Windstorm changed the Tatras (in Slovak), Pravda, 19.5.2014.

Valent, P. - Rončák, P. - Maliariková, M. - Behan, Š. (2016) Utilization of historical maps in the land use change impact studies: A case study from Myjava River basin, Slovak Journal of Civil Engineering, 24(4), pp. 15-26.

Wang, Z. - Batellan, O. - De Smedt, F. (1996) A Distributed Model For Water And Energy Transfer Between Soil, Plants And Atmosphere (Wetspa), Physics and Chemistry of the Earth, 21, pp. 189-193.

Zhang, T. - Zhang, X. - Xia, D. - Liu, Y. (2014) An Analysis of Land Use Change Dynamics and Its Impacts on Hydrological Processes in the Jialing River Basin. Water, 6:3758-3782. 